Information on Research Principles and Findings

\section{in Natural Resource Management}

The following proceedings published by the Canadian Society of Environmental Biologists may be of interest to many readers of the Forestry Chronicle. The CSEB is a non-profit organization of people educated and working in the biological sciences.

\section{Decision-Making:}

The Role of Environmental Information March 18, 1984

A 126 page report containing 9 papers. These proceedings provide an informative collection of papers presented by speakers from government, industry and consulting on the role and importance of environmental information in the process of making resource management or development decisions. The papers cover the areas of: The Decision Process; Case Histories and Experiences; The Public and Decision Making and The Role of Science in Government Policy and Decision Making. Cost $\$ 10$.

\section{Resource Management \\ in the Eastern Slopes \\ March 19, 1983}

A 98 page report containing 12 papers. These papers provide the views of a cross-section of resource users on ways and means of achieving multiple resource use while minimizing conflicts in the important area along the eastern slopes of the Rocky Mountains. Featured are an analysis of governmental policy and planning for the eastern slopes and a panel discussion on resource interaction and conflicts. Cost $\$ 10$.

Available from:

Canadian Society of

Environmental Biologists

Alberta Chapter

Box 12, Substation 11

Edmonton, Alberta

T6G 2E0
Northern Journal of Applied Forestry

The Northern Journal of Applied Forestry was started about a year ago to publish timely, useful information that foresters can apply in managing northern forestland. By northern is meant eastern Kansas and all or parts of the 25 states and six provinces of Canada (Ontario east) to the north and east of Kansas.

The following list of articles from the March 1985 issue gives an idea of its contents: Sequential sampling of stocking; Land-use language; Forest-tree value growth; Volume and taper functions for pitch pine; Upland oak reproduction; Reforestation of orchard stands and savannahs; and Uneven-age management in New England.

Although the journal is doing quite well, it does need additional subscribers to become self-supporting. The editor is also interested in increasing the flow of manuscripts of an applied nature in all areas of natural resources management.

Manuscripts (three copies) and related correspondence should be sent to Harry V. Wiant, Jr., Editor, 113 Scenery Drive, Morgantown, WV, USA 26505. Send inquiries about subscriptions ( $\$ 15$ to CIF members) to NJAF, Society of American Foresters, 5400 Grosvenor Lane, Washington, DC 20814.

\section{Upcoming Meetings}

Western International Forest Disease Work Conference

This meeting will be held at the Westwater Inn, Olympia, Washington from September 24-27. Further particulars are available from: Ken Russell, Dept. Natural Resources, Division of Private Forestry and Recreation. MQ-11, Olympia, WA 98504 (Tel. 206-545-0953); or Walter G. Thies, USDA Forest Service, Forest Sciences Laboratory, 3200 Jefferson Way, Corvallis, OR 97331 (Tel. 503-757-4396).

\section{Forest Land Applications Symposium}

An international symposium on forest utilization of municipal and industrial wastwater and sludge will be held at the University of Washington, Seattle, from June 25-28, 1985.

Forest lands offer attractive alternatives for recycling wastes. The purpose of this symposium is to address the special technical and environmental issues, the managerial and operational aspects, and the future considerations and needs of forest utilization of municipal and industrial wastewater and sludge. Outstanding scientists and contributors in this field will participate in the symposium.

For further information, contact Kathi Grier, College of Forest Resources (206543-2757) for program information; and Conference Registration Office (206-5432310) for questions on registration.

Environmental Influences on Measuring Tree and Stand Increment

IUFRO Working Group S4.01-06 (Mensuration, Growth and Yield) is sponsoring a meeting on this topic in Durham, New Hampshire from September 23-27, 1985. Information on this meeting is available from Dale S. Solomon, Northeastern Forest Experiment Station, USDA Building, University of Maine, Orono, ME 04469. 